\title{
Viability assessment of supplementary vocational education institutions based on staff satisfaction analysis
}

\section{Оценка жизнеспособности учреждений дополнительного профессионального образования на основе анализа удовлетворенности персонала}

\author{
Received: March 2, 2021
}

Accepted: April 30, 2021

\begin{abstract}
The tasks associated with the viability assessment of an organization are relevant for most companies in the current market environment. This can be explained by the fact that the solution of these problems makes it possible to see the state of the enterprise, its possible potential prospects at this juncture, to determine the further strategy, areas of work for successful long-term functioning in the future. The article is concerned with the study of the relevant measurable criteria required for the viability assessment of supplementary vocational education institutions. The methodological basis of the study includes the management concept based on a balanced scorecard, as well as a problem-oriented approach, taking into account the specifics of the activities of institutions providing supplementary vocational education services. Eight groups of criteria for viability assessment of supplementary vocational education institutions with specific indicators have been identified and a scale for their measurement has been proposed. The correspondence of these groups of criteria within the components of the integrated management system has been shown. The satisfaction with the work of staff in the institution is analyzed herein based on the results of a survey of employees for two years.
\end{abstract}

Keywords: Supplementary vocational education, institution viability, criteria for institution viability assessment, integrated management system, educational services.

\begin{abstract}
Аннотация
Задачи, связанные с оценкой жизнеспособности организации, являются актуальными практически для большинства компаний в нынешних условиях деятельности на рынке. Это может объясняться тем, что решение этих задач позволяет увидеть состояние предприятия, его возможные потенциальные перспективы в данный момент, определиться с дальнейшей стратегией, направлениями работ для успешного долгосрочного функционирования в будущем. Статья посвящена исследованию необходимых для оценки жизнеспособности учреждений дополнительного профессионального образования соответствующих критериев, которые должны поддаваться измерению. Методологической основой исследования послужила концепция управления, основанная на системе сбалансированных показателей, а также проблемно ориентированный подход с учётом специфики деятельности учреждений, оказывающих услуги дополнительного профессионального образования. Выделены восемь групп критериев оценки жизнеспособности учреждений дополнительного профессионального образования с конкретными показателями и предложена шкала их измерения. Показано соответствие данных групп критериев в рамках компонентов интегрированной системы менеджмента. В статье проведен анализ удовлетворенности работой персонала в учреждении на основе результатов анкетирования сотрудников за два года.
\end{abstract}

Ключевые слова: дополнительное
профессиональное жизнеспособность учреждения, критерии оценки жизнеспособности учреждения, интегрированная система менеджмента, образовательные услуги.

\footnotetext{
${ }^{29} \mathrm{PhD}$ student, Department of Management in International Business and Tourism Industry, State University of Management, Russian.

${ }^{30}$ Professor, Doctor of Economics, Department of Management and Marketing, Ufa State Aviation Technical University, Russian.
} 


\section{Introduction}

In the modern world, technologies and methods of production and provision of services are rapidly developing and changing. This circumstance requires employees and managers of enterprises to periodically obtain and master new relevant knowledge and practical skills. Therefore, at present, able-bodied citizens strive to receive education, improve their qualifications, undergo professional retraining during their entire working life. This level of education in Russia is provided by the system of Continuing Professional Education (CPE).

Currently, there are many organizations in many areas that have various forms of ownership in the CPE system in Russia. CPE organizations provide services for advanced training, professional retraining, education, and internship.

CPE institutions are the most important element of the subsystem of lifelong education for adults, which is distinguished by its multifunctionality, dynamism, and the outstripping nature of development concerning the objects of professional activity of students. The concept of lifelong education consists of continuous professional development, skills improvement, and adjustment of the individual professional trajectory.

Thus, the work of the CPE institutions plays an important role in the educational process of the state and society. The professionalism of specialists at enterprises and organizations of the country depends on how effectively these institutions function.

\section{Literature Review}

The system of Russian higher and additional professional education is in constant reform to improve it (Afanasev et al, 2019; Garnov et al, 2019). This applies both to the process of providing educational services and to improving the financial performance of educational institutions.

The conditions of the modern market allot very difficult tasks for a supplementary vocational education institution (SVEI), which cannot always be described by classical formulas. Nowadays, an increase in the need for viability assessment processes is due to many internal and external factors, including high competition among educational institutions (Lien, 2008; Poyago-Theotoky \& Tampieri, 2016), changes in the requirements for supplementary vocational education as a result of the transformation of the operating environment (Medvedeva, 2015). In these conditions, the issues of justification and selection of criteria for assessing the current state of SVEI institutions in order to ensure a sufficient level of viability acquire particular relevance.

It should be noted that the problem of assessment criteria justification has been the subject of research by many scientists (for example, Liu et al, 2012; Papenbrock et al, 2015; Mandros et al, 2018; Mandros et al, 2020; Liu et al, 2020), but the performance assessment criteria, particularly, the SVEI viability assessment criteria are studied insufficiently, especially in terms of the transformation of consumer preferences, increase in customer requirements for educational services and service functions, and individualization of needs. Modern employees often strive to express their own individuality, due to which only the SVEI able to meet personal requirements with the least resources can achieve maximum results (Raza \& Zainab, 2019; Keptner \& Rogers, 2019; Faeq, 2020).

Thus, the systematization of the above problems that arise in the process of viability assessment of an SVEI made it possible to distinguish the key points when trying to transform these processes into a measurable science. It is difficult to conduct a correct assessment of an SVEI and determine the effectiveness of the implemented relationships due to the following reasons (Shirokova, 2011; Pimenova, 2012; Kobyakov, 2015):

first, the presence of difficulties in assessing the emerging long-term effects of the activities of the SVEI;

second, due to the difficulties in differentiating the results of educational services of the SVEI and the management of the institution as a whole, since partially educational results are indirectly embodied in other processes and functions of consumers of educational services, which include production, development and research, etc.;

third, due to the lack of financial expression of indicators of the SVEI viability;

fourth, since the main parameters in a modern SVEI are the relationships between the participating subjects in the process of additional education, this complicates the development of a system of indicators in a networked economy able to fully characterize all possible client 
communications and the value created during their implementation. It should be noted that the main difficulty lies not in the number of relationships or interactions, since modern information and communication technologies and principles of building databases can make it possible to structure, process, and manage large amounts of information, but in the complexity of assessing each level of viability, since each of the directions estimates is unique.

Based on the foregoing, the purpose of this study should be formulated as the definition of criteria for viability assessment of SVEIs and scales of their measurement.

\section{Methodology}

Within the framework of this purpose, the following research logic is proposed. First, it is necessary to consider the grouping of criteria for viability assessment of an SVEI with specific indicators within the components of an integrated management system (IMS). Then, as an example, the authors will present the data from two questionnaires of the staff of the SVEI Private Educational Institution "Interdisciplinary Institute", showing the level of staff satisfaction on various issues, their vision and proposals, including for increasing the viability of the SVEI.

The problem of substantiating the criteria for viability assessment of organizations, discussed by practitioners and theorists, has not yet found its comprehensive systemic solution, the plane of which should lie within the framework of the use of comprehensive analysis methods and tools tested in practice. From the authors' point of view, the basis for the development of a system for viability assessment of an SVEI is to introduce an integrated management system into the activities of the institution, which includes a quality management system, environmental management, health and safety management and a customer-oriented approach.

In the context of the purpose hereof, the viability of the SVEI is not a set of separate functions, but a combination of interrelated processes that are integrated into a single system for managing the educational process of the institution. Analyzing the role of SVEIs in modern society, it can be noted that it goes beyond the intra-organizational framework. The institution should strive to ensure effective coordination of the activities of all functional departments in order to better understand customer relationships, customer service and attraction, personnel management, etc. (Ostrozhnaya, 2015; Bolbakov, 2016; Popkova et al, 2016; Zagoruiko, 2018).
In this regard, the efficiency types that can characterize the processes of an SVEI should be considered. Thus, according to the classical theory, the concept of sustainable development has recently dominated, which involves the assessment of economic, social, and/or other types of performance in the activities of business entities and the economy as a whole (Baporikar, 2020; Menon \& Suresh, 2020; Agirreazkuenaga, 2020). Consider the concept of each efficiency type.

1. Economic efficiency is the result of the ratio of indicators of profitability to the resources used and total costs. When the profitability is higher than the second component, then the goals are achieved, the needs are satisfied, the resources are sufficient. In the opposite case, there is no economic effect, then the institution receives losses. The essence of cost-effectiveness is that the institution, through the available resources, obtains more results from its activities, recouping the costs of the acquired resources (De Martino et al, 2020).

2. Social efficiency characterizes the level of satisfaction of social needs, demonstrates how the focus of economic activity on the person (personality) him/herself meets the existing needs. The analysis of the quality and volume of social benefits received by the population is of great importance in social efficiency assessment. These social benefits determine the level of health care, education, and housing conditions of citizens (Donina, 2013).

3. Environmental efficiency is the compliance of production activities with established standards of environmental impacts that can be objectively measured. In accordance with GOST R ISO 14031-2001, environmental efficiency is the results of managing the greening of activities that can be assessed in relation to public policy, its objectives and goals in the environmental sphere (Alibašić. \& Crawley, 2018; Dima \& Meghisan-Toma, 2018; Rodríguez-García et al, 2019).

To assess the viability of SVEIs within the IMS, it is advisable to use a management concept based on the well-known Balanced Scorecard, the main idea of which is to divide the strategic goals of the functioning of institutions into several groups (Kaplan \& Norton, 1996). In relation to the activities of SVEIs, it is as follows:

1. the level of financial security of the SVEI, which characterizes the main parameters of financial control;

2. the level of implementation of relationships with personnel;

ISSN $2322-6307$ 


\section{AMAZONDA \\ Invertiga}

3. the level of effectiveness of the SVEI in terms of internal processes, which characterizes the effectiveness of the organization of client relations of the institution;

4. the level of quality of relationships with clients, characterizing the possibilities of improving the quality of service;

5. the level of SVEI funding, which characterizes the costs aimed at maintaining long-term relationships with staff;

6. the level of quality of personnel management, reflecting the processes of selection, adaptation, training and education (advanced training, professional retraining, etc.), motivation;
7. the level of compliance with environmental standards (the level of costs for utilities per student, the amount of costs for utilities, etc.);

8. the level of subjective satisfaction by consumers with the service and services provided, which characterizes the development of the service component.

The achievement of the established indicators ensures the achievement of the goals of the institution (Barkov, 2014; Stevens, 1946). All of the above criteria correspond to the assessment of the four components of the IMS: quality management system, environmental management, health and safety management, and a customer-centered approach (Figure 1).

\begin{tabular}{|c|c|c|}
\hline \multicolumn{3}{|l|}{ Quality management system } \\
\hline $\begin{array}{l}\text { 1) Financial management level of } \\
\text { SVEI } \\
\text { Customer-centered approach }\end{array}$ & $\begin{array}{l}\text { 3) Performance level of } \\
\text { internal processes of SVEI }\end{array}$ & 6) Personnel management quality level \\
\hline $\begin{array}{l}\text { 4) The level of quality of } \\
\text { relationships with students }\end{array}$ & 5) SVEI funding level & $\begin{array}{l}\text { 8) The level of subjective satisfaction of } \\
\text { clients with educational services and } \\
\text { services provided }\end{array}$ \\
\hline $\begin{array}{l}\text { Health and safety management } \\
\text { 2) Level of implementation of } \\
\text { relationships with personnel }\end{array}$ & & $\begin{array}{l}\text { Environmental management } \\
\text { 7) Compliance with environmental } \\
\text { standards }\end{array}$ \\
\hline
\end{tabular}

Source: compiled by the author

Figure 1. Grouping criteria for the viability assessment.

Summarizing the above, it can be concluded that the most important part in the viability assessment of an SVEI is a comprehensive analysis of all areas of activity, while special attention should be paid to relationships with customers, staff, etc.
Having conducted an expert assessment, the authors found that the most important elements of the viability of an SVEI were the level of effectiveness of internal processes of the SVEI, the level of financial management of the SVEI, and the funding level of the SVEI (Table 1).

Table 1.

Calculation of coefficients of the relative importance of groups of vitality indicators.

\begin{tabular}{|c|c|c|c|c|c|c|c|}
\hline Group & Expert 1 & Expert 2 & Expert 3 & Expert 4 & Expert 5 & & $\mathrm{C}_{\mathbf{r i}}$ \\
\hline $\begin{array}{l}\text { 1) Financial management level of } \\
\text { the SVEI }\end{array}$ & 5 & 4 & 7 & 6 & 5 & 27 & 0.150 \\
\hline $\begin{array}{l}\text { 2) Level of implementation of } \\
\text { relationships with personnel }\end{array}$ & 2 & 5 & 2 & 1 & 3 & 13 & 0.072 \\
\hline $\begin{array}{l}\text { 3) Performance level of internal } \\
\text { processes of the SVEI }\end{array}$ & 8 & 6 & 8 & 5 & 7 & 34 & 0.189 \\
\hline $\begin{array}{l}\text { 4) The level of quality of } \\
\text { relationships with students }\end{array}$ & 3 & 1 & 6 & 4 & 8 & 22 & 0.122 \\
\hline 5) Funding level of the SVEI & 7 & 8 & 3 & 2 & 4 & 24 & 0.133 \\
\hline $\begin{array}{l}\text { 6) Personnel management quality } \\
\text { level }\end{array}$ & 4 & 3 & 4 & 3 & 1 & 15 & 0.083 \\
\hline $\begin{array}{l}\text { 7) Compliance with environmental } \\
\text { standards }\end{array}$ & 6 & 2 & 5 & 8 & 2 & 23 & 0.128 \\
\hline $\begin{array}{l}\text { 8) The level of subjective } \\
\text { satisfaction of clients with } \\
\text { educational services and services }\end{array}$ & 1 & 7 & 1 & 7 & 6 & 22 & 0.122 \\
\hline TOTAL & 36 & 36 & 36 & 36 & 36 & 18 & 1.000 \\
\hline
\end{tabular}

Source: compiled by the autor. 
As part of this study, let us assess the viability of an SVEI based on the analysis of personnel satisfaction (the level of implementation of relationships with personnel), other groups will be analyzed in further studies.

\section{Results and Discussion}

In 2016, a questionnaire was drawn up and an anonymous survey of teachers and other employees of the Private Educational Institution "Interdisciplinary Institute" was carried out to assess staff satisfaction with management procedures, work organization in the SVEI, the level of wages, etc. (Akhmetshin \& Ibatullin, 2016). The staff answered several questions. The results of the questionnaire in the context of the age of the respondents are presented in Table 2.

Moreover, the authors calculated the overall employee satisfaction using the following algorithm:
1. Calculate the average level of satisfaction for each section of the questionnaire.

2. Compare the level of satisfaction for each age group with the average level of satisfaction for each section of the questionnaire.

3. Determine the number of sections in which the level of satisfaction is above average for each age group.

4. Calculate the proportion of sections in which the level of satisfaction is above the average - this is a complex satisfaction (CUag) for each age group.

In Table 2, age groups in which the level of satisfaction is below average are highlighted in yellow in each section. Moreover, the calculation of the complex satisfaction of SVEI personnel was carried out, the results of which are presented in Figure 2.

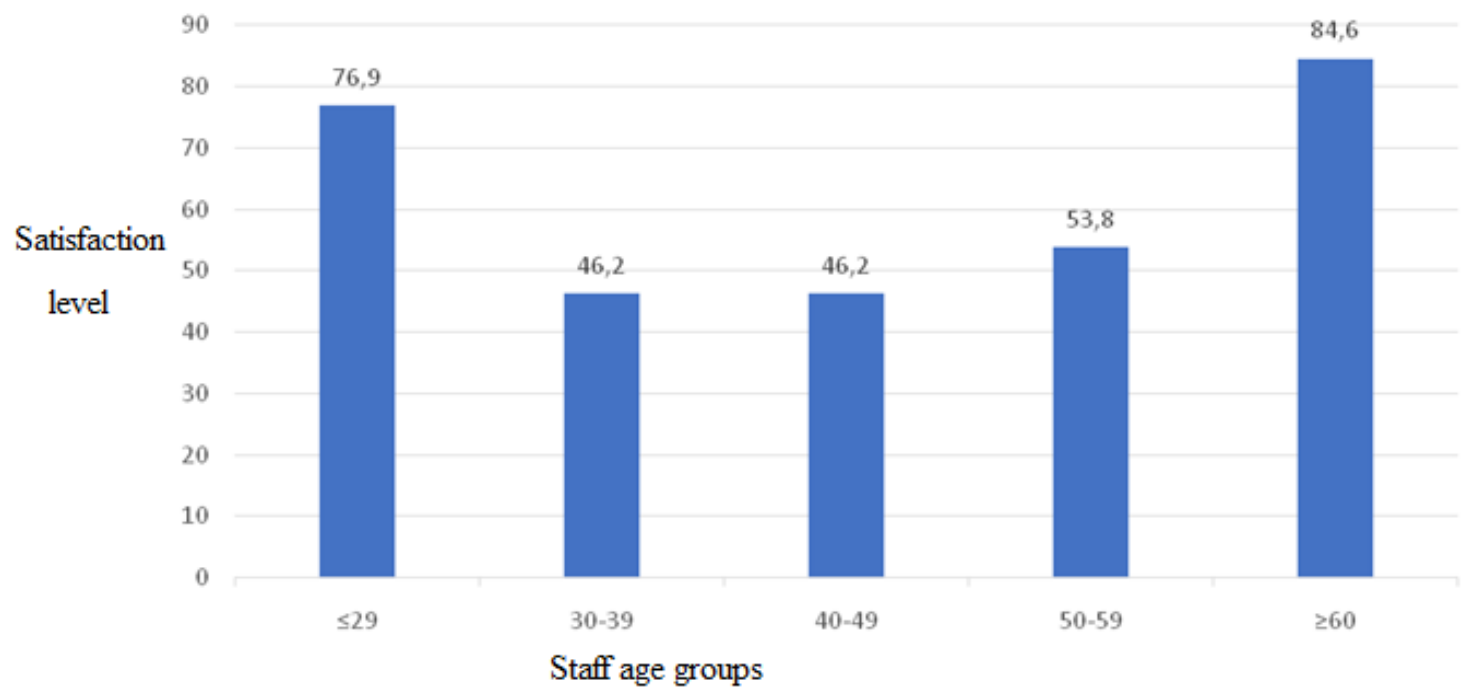

Source: the author's calculation based on data from a survey of personnel of the Private Educational Institution "Interdisciplinary Institute"

Figure 2. The general level of satisfaction of employees of the Private Educational Institution "Interdisciplinary Institute", in \%

The analysis of the data presented in Table 2 makes it possible to conclude that the employees are the most satisfied with labor relations, work organization at the institute and performance. The employees are least satisfied with social security and guarantees at the institute, bonuspenalty system, organizational status and career growth, and the content of work in the workplace.

The overall level of satisfaction shows that the employees over 60 and young professionals are the most satisfied. The least satisfaction is experienced by specialists in two groups: aged 30 to 39 and 40 to 49 . 
Table 2.

Staff satisfaction assessment of the Private Educational Institution "Interdisciplinary Institute"31

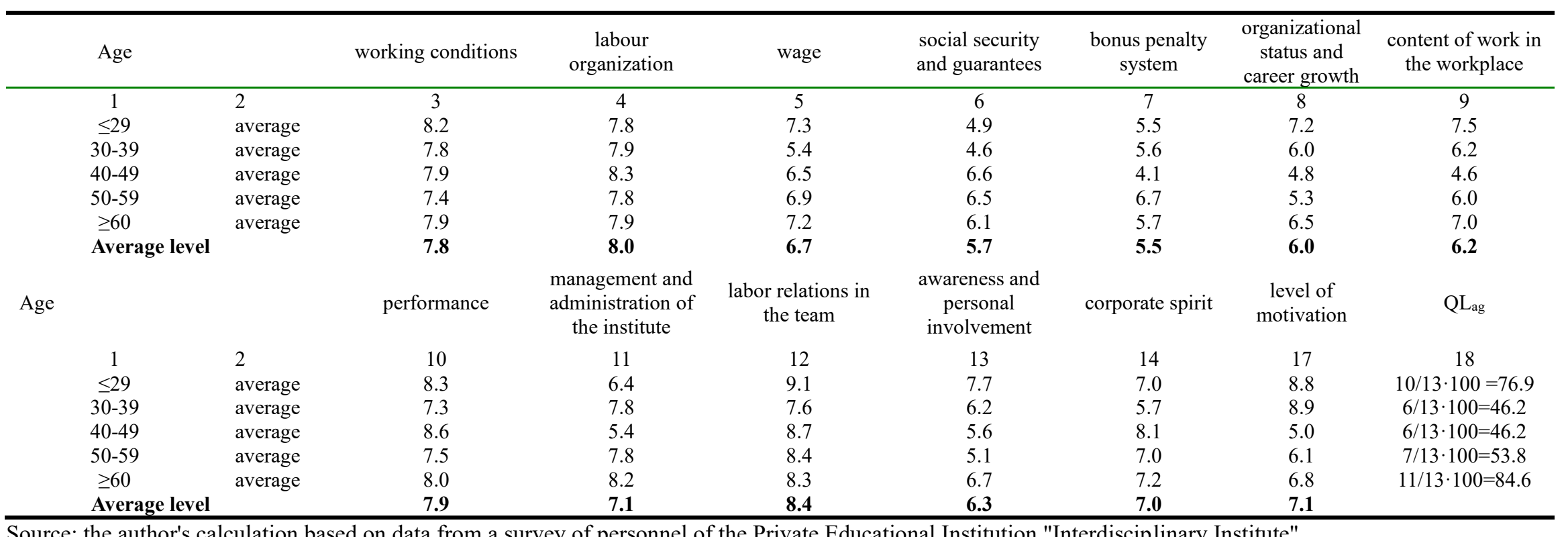

Source: the author's calculation based on data from a survey of personnel of the Private Educational Institution "Interdisciplinary Institute"

${ }^{31}$ The groups of factors that received the minimum ratings are marked in yellow. 
In 2017, an anonymous survey of employees of the Private Educational Institution "Interdisciplinary Institute" was also conducted, the results of the survey showed that about $50 \%$ of employees are generally satisfied with the organization of the labor process, the level of wages, and the quality of services provided. At the same time, many of them expressed dissatisfaction with this or that direction of the activity of the Private Educational Institution "Interdisciplinary Institute". Thus, with regard to wages, $30 \%$ of the respondents answered that they would like to increase the standard of living provided by income from work, another $12 \%$ believe that there is a discrepancy between benefits and social package for personal needs.

In addition to answering the questions, respondents noted the necessary measures to increase the viability of the SVEI, namely:

a) the need to improve the quality of the work of the executives and reduce errors;

b) the need to reduce the staff of department managers;

c) insufficient qualifications, competence, mobility of employees of departments;

d) insufficient equipment of the Private Educational Institution "Interdisciplinary Institute" with the necessary instruments and devices;

e) the need to introduce distance technologies for new educational programs, not only in the field of labor protection and safety at work;

f) the need to have a distance learning version for all educational programs in demand for their implementation outside the Republic of Bashkortostan in the event of a change in the needs in society, the possibility of implementation in the domestic republican market.

\section{Conclusions}

As a result of the study of the practical aspects of the formation of the system for assessing the viability of SVEIs, the authors have determined the conditions for the implementation of these processes. The study proposes a system of criteria for the viability assessment of SVEIs, which is a set of methods and techniques for understanding the object of control, aimed at checking the activities of enterprises in order to study the state of its economy and finances, ensuring the legality, reliability, and expediency of operations, efficient use of resources, the safety of assets, timeliness of risk identification based on the use of legislative, regulatory, reference, statistical and organizational and administrative information.

Moreover, it can be concluded that the quality of personnel management is highly important for increasing the viability of SVEIs.

\section{Bibliographic references}

Agirreazkuenaga, L. (2020). Education for Agenda 2030: What Direction do We Want to Take Going Forward? Sustainability, 12(5), 2035, https://doi.org/10.3390/su12052035

Afanasev, N., Okhlopkova, D., Malanchuk, I., Gridina, V., \& Petrova, L. (2019). Reforms in the field of secondary and higher public education in the Russian Federation as a factor of modernization at the present stage. Amazonia Investiga, 8(22), 658-664. Retrieved from https://amazoniainvestiga.info/index.php/amazo nia/article/view/816

Akhmetshin, A.A. \& Ibatullin, U.G. (2016). Preparation for implementation of client-oriented approach in organization of additional professional education. International Journal of Economics and Education, 2 (3), 31-40.

Alibašić, H. \& Crawley, W. (2018). Developing and Sustaining Sustainability-Related Academic Programming: Observations of Emerging Practices. Creighton Journal of Interdisciplinary Leadership, $\quad 4(1), \quad 27, \quad$ DOI: http://dx.doi.org/10.17062/cjil.v4i1.66

Baporikar, N. (2020). Finer Student Engagement via Quality and Lifelong Learning for Sustainable Education. International Journal of Political Activism and Engagement, 7(4), 38-55, https://doi.org/10.4018/ijpae.2020100104 Barkov, A.S. (2014). Formation of the system of balanced indicators to build a model of organizational development of the company. Economics and Management in the XXI century: trends, 16, 56-61 (in Russian).

Bolbakov, R. G. (2016). Cognitive methods for educational quality assessment. Educational resources and technology, 1(13), 34-39, https://doi.org/10.21777/2500-2112-2016-1-3439

De Martino, M., Tkach, G. F., \& Kovalenko, S. A. (2020). Modern Trends in Public Funding of Higher Education. Higher Education in Russia, 29(3), 136-152, https://doi.org/10.31992/08693617-2020-29-3-136-152

Dima, A.M. \& Meghisan-Toma, G.-M. (2018). Research on implementing education for sustainable development. Proceedings of the International Conference on Business Excellence, 12(1), 300-310, https://doi.org/10.2478/picbe-2018-0027 


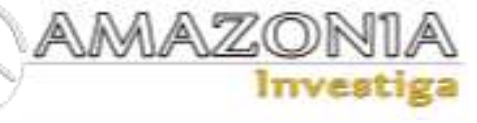

Donina, I.A. (2013). The Problem of Efficiency Assessment of Modern General Education Organization: Social and Economic Aspects. Bulletin of Yaroslav the Wise Novgorod State University, 74 (2), 19-22 (in Russian)

Faeq, M. (2020). Performance Evaluation Criteria Development Process for Academic Staff at Universities. Black Sea Journal of Management and Marketing, 1(1), 59-70, https://doi.org/10.47299/bsjmm.v1i1.17

Garnov, A., Bykova, O., Brykin, A., \& Gudilin, A. (2019). Russian education trends: protracted regression or moving forward. Amazonia Investiga, 8(23), 308-317. Retrieved from https://amazoniainvestiga.info/index.php/amazo nia/article/view/873

Kaplan R.S., \& Norton D.P. (1996). The Balanced Scorecard: Translating Strategy into Action. Boston: Harvard Business Review Press. Keptner, K.M. \& Rogers, R. (2019). Competence and Satisfaction in Occupational Performance Among a Sample of University Students: An Exploratory Study. OTJR Occupation Participation and Health, 39(4), 204-212, https://doi.org/10.1177/1539449218813702

Kobyakov, P.K. (2015). Integral Evaluation of Educational Institutions Efficiency by a Set of Interval Expert Evaluations of Private Indicators. Technical and Technological Problems of Service, 31, 103-108, https://cyberleninka.ru/article/n/integralnayaotsenka-effektivnosti-obrazovatelnyhuchrezhdeniy-po-sovokupnosti-intervalnyhekspertnyh-otsenok-chastnyh-pokazateley

Russian)

Lien, D. (2008). Economic analysis of transnational education. Education Economics, $16(2)$, 149-166, https://doi.org/10.1080/09645290701273475 Liu, J., Li., J., \& Liu, C. (2012). Discover Dependencies from Data-A Review. IEEE Transactions on Knowledge and Data Engineering, 24(2), 251-264, https://doi.org/10.1109/tkde.2010.197

Liu, R., Simon, E., Amann, B., \& Gançarski, S. (2020). Discovering and merging related analytic datasets. Information Systems, 91, 101495, https://doi.org/10.1016/j.is.2020.101495

Mandros, P., Boley, M. \& Vreeken, J. (2018). Discovering Reliable Dependencies from Data: Hardness and Improved Algorithms. 2018 IEEE International Conference on Data Mining (ICDM), Singapore, 317-326, https://doi.org/10.1109/icdm.2018.00047

Mandros, P., Boley, M. \& Vreeken, J. (2020). Discovering dependencies with reliable mutual information. Knowledge and Information
Systems, 62(11), 4223-4253, https://doi.org/10.1007/s10115-020-01494-9

Medvedeva, T.A. (2015). University Education: The Challenges of 21st Century. Procedia Social and Behavioral Sciences, 166, 422-426, https://doi.org/10.1016/j.sbspro.2014.12.547

Menon, S. \& Suresh, M. (2020). Synergizing education, research, campus operations, and community engagements towards sustainability in higher education: a literature review. International Journal of Sustainability in Higher Education, 21(5), 1015-1051, https://doi.org/10.1108/ijshe-03-2020-0089 Ostrozhnaya, E.E. (2015). Evaluation of quality of additional professional education. Scientific bulletin of the Southern Institute of Management, 4 , https://cyberleninka.ru/article/n/otsenkakachestva-dopolnitelnogo-professionalnogoobrazovaniya (in Russian)

Papenbrock, T., Ehrlich, J., Marten. J., et al (2015). Functional dependency discovery. Proceedings of the VLDB Endowment, 8(10), 1082-1093,

https://doi.org/10.14778/2794367.2794377

Pimenova, N.Yu. (2012). Designing the model of competence of experts on quality estimation of programs of additional professional education. Territory of new opportunities. Bulletin of Vladivostok State University of Economics and Service, 5, 133-154 (in Russian)

Popkova, A.A., Baikina Y.O., \& Kalinina A.V. (2016). Effectiveness evaluation of the programs of additional professional education. Bulletin of Surgut State Pedagogical University, 3, 24-28, https://cyberleninka.ru/article/n/otsenkarezultativnosti-programm-dopolnitelnogoprofessionalnogo-obrazovaniya (in Russian) Poyago-Theotoky, J. \& Tampieri, A. (2016). University Competition and Transnational Education: The Choice of Branch Campus. The B E Journal of Theoretical Economics, 16(2), 739-766, https://doi.org/10.1515/bejte-20150052

Raza, A. \& Zainab, H. (2019). The good teacher attributes - a cross sectional study on teaching evaluation at rehman medical college, Peshawarq. The Professional Medical Journal, 26(06),

https://doi.org/10.29309/tpmj/2019.26.06.3445

Rodríguez-García, A.-M., Belmonte, J.L. \& Agreda, M. (2019). Productive, Structural and Dynamic Study of the Concept of Sustainability in the Educational Field. Sustainability, 11(20), 5613, https://doi.org/10.3390/su11205613

Shirokova, I.E. (2011). Modern approaches to the evaluation of the efficiency of training specialists in institutions of additional professional education. Scientific notes of the 
Transbaikal State University. Series: Professional Education, Theory and Methodology of Education, 6, 207-211 (in Russian)

Stevens, S.S. (1946). On the theory of scales of measurement. Science, 103, 2684, 677-680, https://psychology.okstate.edu/faculty/jgrice/psy c3214/Stevens_FourScales_1946.pdf

Zagoruiko, L. (2018). Approaches to educational quality assessment: The European context. Comparative and pedagogical studies, 1, https://doi.org/10.31499/23065532.1.2018.140217 